\title{
Framework for Implementation of Education Policy in the Perspective of Education Management in Indonesia
}

\author{
Muhdi Muhdi \\ Department of Educational Management, Post Graduate Program, Universitas PGRI Semarang, Indonesia
}

Received October 6, 2019; Revised October 30, 2019; Accepted November 8, 2019

Copyright $\bigcirc 2019$ by authors, all rights reserved. Authors agree that this article remains permanently open access under the terms of the Creative Commons Attribution License 4.0 International License

\begin{abstract}
This study seeks to analyze the implementation of public policies related to education as a result of the decentralization of education in Indonesia. This study focuses on the phenomenon of regional autonomy policy implementation, and how the model framework is in the implementation of education policy in the era of regional autonomy. Using a qualitative approach with a descriptive analytical method, the results of the study revealed that there are four main factors that need to be referenced in policy making and implementation of education policy in Indonesia. Specifically, the results of the study revealed that important considerations in the implementation of education were related to translation skills, human resource management capabilities, the number of implementers and accountability. By considering phenomena and problems arising from decentralization, the framework is considered to be in accordance with the reality of how education policies are implemented in Indonesia.
\end{abstract}

Keywords Education Policy, Policy Making, Implementation, Education Management, Institutional Perspective

\section{Introduction}

The essence of regional autonomy in the field of education is to give authority and responsibility to regional governments in carrying out educational policies so that national goals for the intellectual life of the nation can be achieved (Kristiansen, 2006). As long as education is centralized, efforts to expand access and improve the quality of education have not been achieved optimally. As confirmed by Sidi (2001) that education development which has been dominated by the central government has proven to be less effective. This is evident in the fact that various investment programs that have expanded access to education and improved quality have not been able to achieve the expected results

Education is a decentralized field, because education is one of the important public services in nation-building and there are demands from the community and local government that the government should immediately implement decentralization in the field of education (Bjork, 2003). This is as stated by Stinnette (1993) that the implementation of education decentralization is due to pressure following the decline in the quality of education. It was further said that the implementation of education decentralization was faced with pressures that had never been encountered before, such as underachievement, teacher and student relations in the teaching and learning process which got worse, inefficient bureaucracy, increasingly damaged facilities, decreasing parental involvement, and fiscal cuts, many school system supervisors and school boards in big cities are turning to business management practices in the form of decentralized authority and participatory decision-making to get solutions (Simatupang, 2009; Bjork, 2005; Toi, 2010; Samosir, 2008).

Furthermore Ornelas (2000) in his article titled "The Politics of Educational Decentralization in Mexico" said that the background of the demands of decentralization because the old system was very vulnerable to conflict and dominance of the National Teachers' Union and unable to raise quality standards. Other empirical studies in some regions, especially in developing countries, also revealed that decentralization of education encourages the privatization of education management practices and systems as well as the encouragement for accountability (Gamage \& Sooksomchitra, 2006; Davies et al., 2003; Edwards Jr \& DeMatthews, 2014; Gershberg et al., 2009; Ornelas, 2004; Schiefelbein, 2004). Meanwhile, Klugman (1994) and Winkler (1989: 4) state that a highly centralized education system is perceived to be relatively expensive and inefficient, poor in quality, and unresponsive to the interests and needs of parents and 
local employers. Such a centralized education system is considered relatively expensive, inefficient, of poor quality, and not responsive to the interests and needs of parents and the local labor market. So that the decentralization of education is needed because of the tendency of a less effective centralized education system.

Education is one of the decentralized fields in order to achieve the level of success expected by the central and regional governments (Muhdi, 2012). With the decentralization of national education management, there will be a closeness between education services and the community served. This closeness will make the process of educational management interaction in terms of planning, organizing, leadership, and control that can be carried out effectively and efficiently. Based on Law No. 22 of 1999 which was perfected by Law No. 32 of 2004 concerning Regional Government stipulates that education and culture are one of the fields of government whose implementation is delegated to district/city governments. This delegation aims to provide better quality, relevant and equitable educational services to the local community. As a manifestation of a public policy, in principle the implementation of regional autonomy in the field of education in Indonesia as in other countries, according to Baedhowi (2009: 88) who has the aim to (1) increase the effectiveness, efficiency and relevance of education, (2) increase the delivery of education that is transparent and accountable; and (3) empower all components of education stakeholders in improving the quality of education.

The implementation of educational policies has been widely discussed in various studies (Young \& Lewis, 2015; Coburn et al., 2016). This is related to the vision of education that is usually an idealistic concept, so that policy implementation functions as a platform for the actualization of that vision. Several studies in various countries, like China (Liu et al., 2017), Singapore (Seow et al., 2019), Turkey (Egilmez, 2018; Atasoy \& Cemaloglu, 2018), United States and India (Gillespie, \& Fairbairn, 2019), and European Union (Wyse \& Ferrari, 2015) show that education policy involves many parties and the roles needed to make it implemented.

Elmore (2002) underlines that the implementation of education policies leads to efforts to improve school performance so that they are well managed. These efforts require increasing the knowledge and skills of teachers and changing their knowledge of content and ways of teaching and the academic development of teachers and students (Elmore, 2004). Although school performance can be determined from the quality of teachers, school management and student knowledge, implementing efforts focused on the teacher-student side alone cannot comprehensively assess whether education policies have been implemented or not. This is because educational policy will involve many stakeholders, ranging from the community, policy makers (Spillane, 2000; Xu \& Mei, 2018), academia and educational institutions in general
(Yarime et al., 2012; del Mar Alonso-Almeida et al., 2015; Adomssent et al. 2014), local government (Honig, 2006) and even industry as end-user graduates (St. Amant, 2003). The study of Honig (2004) gave rise to the concept of an 'intermediary organization' as an important participant in the implementation of educational policies. Furthermore, Honig (2004) with a case study in Oakland that these intermediary organizations function to provide knowledge, political / social ties, and administrative infrastructures as implementation resources. This shows that education policy making must be seen in a broad framework as a value chain and institution from the top-down (Rollan \& Somerton, 2019), and its implementation flows from the bottom-up through a series of actualization, control. In some of these contexts, this study seeks to underscore how an education policy is made, the capabilities needed, and its evaluation. The novelty point of this study which is different from previous research focuses emphasizes that in the first stage, especially in Indonesia, the role of the policy -makers and politics is very important here, the role of the community and academia is needed to provide positive aspirations for the development of education. The second value is the focus of Honig's study (2004), which seeks to explore the capabilities of intermediaries needed by managers of secondary level education, such as the education office, and the principal in implementing it. However, different from Honig (2004), this study offers an intermediary concept in terms of personal, not organizational abilities. This is important because the success of policy implementation depends on many ways on the level of secondary education managers, such as the education office, who must be able to read government policies and actualize them at the school environment, for instance. This focus is also different from Coburn et al. (2016) which emphasizes the accountability of management system approach in implementing educational policies. DeFeo et al. (2018), on the other hand, uses the regulatory flow focus, but less emphasis on the ability of mid-level managers.

Third, this study provides a theoretical framework for implementing education regulations and policies from top level, middle level education managers to evaluation at school level. This is related to the gap phenomenon that this kind of study is needed because the change in the national level policy system in Indonesia from centralization to decentralization within the framework of regional autonomy, where education is one of the decentralized aspects. Therefore, the implementation of regional autonomy policy and how the model framework in the implementation of education policy in the era of regional autonomy are the focuses of this research. Although the education sector is one of the decentralized fields of government and more than ten years of policy has been implemented in Indonesia, the results have not been encouraged and some even call it a failure. Therefore, it is deemed necessary to know how to implement education 
policies. From the results of this study, this study developed a model framework for implementing education policies that were appropriate in the era of regional autonomy in Indonesia.

\section{Educational Organization and Management}

\subsection{Institutional Perspective in Educational Management Reform}

The enactment of regional autonomy in the field of education requires institutional reform (Wael \& Laurens, 2015). In the implementation of the regional autonomy policy in the fields of education, organization and management of education is one component that must be structured institutionally starting from the district/city level to the school level. These components include (1) structuring the organizational structure and procedures, (2) the main tasks and functions of organizational units, and (3) the process of filling positions.

In structuring the organization and management of district/city education, its implementation can be measured using indicators of economy, efficiency, effectiveness, transparency, and accountability (Mbiti, 2016). Thus, organizational management and education management were carried out by considering funds or budgets in a reasonable manner (economy), utilizing or empowering human resources, funds and available facilities (efficiency), in accordance with the interests of improving organizational performance to support the achievement of programmed goals (effectiveness), carried out objectively and transparently for the benefit of the organization and good service (transparency), and must be truly accountable for both the process and the impact of organizational structuring and education management (accountability).

\subsection{Education Funding}

Education funding is a very dominant part in implementing education policies. The components of education funding can include (1) planning and submission of budget allocations, (2) budget allocation and distribution, (3) budget spending and utilization, and (4) accountability for budget use.

Education budget according to article 46 paragraph 1 of Law no. 20 of 2003 concerning the National Education System and article 2 paragraph 1, 2 Government Regulation No. 48 of 2008 concerning Education Funding is a joint responsibility between the government (central government, provincial government and district/city government) and the community (organizers of education units, students, parents/guardians and other parties who care about education). Education can be grouped into education organized by the central government, education organized by local governments, and education organized by the public with a funding system that can be different. The education funding system in Indonesia according to Ghozali (2012) includes the structure and characteristics of education costs that reflect the need for educational resources for the management and administration of education, the education budget and how to allocate, distribute, and use education funds. Education costs represent the monetary value of the educational resources needed to manage and organize education.

Budget planning, budget allocation, and distribution are stages that become the authority of budget policy makers, namely the Mayor and the regional parliament. While spending and utilizing budget is the authority of implementing the policy, namely the education office, which must be fully accountable for the use of its budget. The implementation of education funding in education autonomy can be measured using indicators of economy, efficiency, effectiveness, transparency, and accountability. Thus, it can be known whether the education financing component is planned in accordance with the principle of economy, carried out by empowering human resources and other supporting facilities owned (efficiency). It is also needed for considering the budget according to needs and actually used to support the specified program (effectiveness), and carried out objectively and transparently in accordance with the provisions in force (transparency). Lastly, it must really be accountable both in its allocation, distribution, and the results achieved (accountability).

\subsection{Educational Facilities and Infrastructure}

Educational facilities and infrastructure within the framework of regional autonomy in the field of education include at least (1) procurement, maintenance and improvement of facilities and infrastructure, (2) utilization of available educational facilities and infrastructure. To find out efforts to improve educational facilities and infrastructure starting from procurement, utilization, maintenance, and improvement can be measured using indicators of economy, efficiency, effectiveness, transparency, and accountability.

Thus, it can be known whether efforts to improve educational supporting infrastructure has been carried out with the principle of saving according to the needs (economy), carried out by utilizing or empowering human resources, funds and facilities available (efficiency). It is also worthy to note that the utilization of educational facilities and infrastructure is in accordance with the needs to support the achievement of objectives and program determined (effectiveness), and carried out objectively and transparently starting from planning, procurement, utilization, maintenance and improvement (transparency). Lastly, the utilization of educational facilities and infrastructure can be accounted for both their 
implementation, quality and quantity in accordance with the plan (accountability).

\section{Implementation of Education Policy in the Context of Management}

A public policy starts from the formulation, implementation, and evaluation. The implementation of educational policies is an effort to implement a policy goal that has been decided by the policy maker in an education policy. In other words, policy implementation is essentially a way for a policy to achieve its objectives.

An education policy can be directly implemented in the form of a program or a derivative policy that must be made to explain the policy. Dwijowijoto (2004: 159) illustrates in Figure 1.

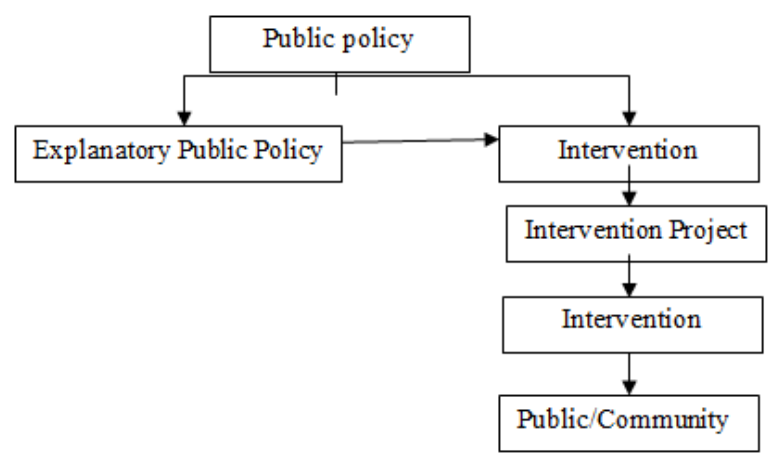

Figure 1. Public Policy Implementation

Public policies including education policies require explanatory policies for implementing regulations in the form of policies in the form of laws or regulations, whereas policies that do not require explanatory policies can be directly implemented or operationalized, including Presidential Decrees, Presidential Instruction, Ministerial Decrees, Mayor Decrees, Decrees of the Head of the Education Office, and others.

Basically, policy implementation is an activity of organizing, leading the implementation, and controlling the implementation of activities in the context of management within the framework of organizing - actuating and controlling. Public policy starting from policy formulation to policy implementation is essentially a common mechanism in management, especially public sector management. Public sector management will always begin with the mission, vision, plans, strategies, programs, projects, activities and feedback.

Implementation of policies including educational policies is an activity that is in the management process. In management activities, there are planning, organizing, actuating, and controlling processes. Implementation of policies in the context of management is in the organizing, and controlling sections. According to Dwijowijoto (2004), the implementation of policies within the management context is within the framework of organizing - leading controlling. Activities needed in the context of public policy include the implementation of management activities of organizing, actuating, and controlling According to Daft and Lane (2007) in essence, management activities can be described as follows:

1. Planning is a management function with regard to defining objectives for future organizational performance and deciding on the tasks and resources used to achieve these goals.

2. Organizing is a management function related to assignments, grouping tasks into departments and allocating resources to departments.

3. Leading management functions is with regard to how to use influence to motivate employees in achieving organizational goals.

4. Controlling management functions is related to supervision of employee activities to keep the organization on track with targets and make corrections if necessary.

Dwijowijoto (2004) by adapting the thoughts of James A.F. Stoner (2009), R. Edward Freeman (2005), and Daniel R. Gilbert Jr. (1996), describe the stages of management activities in the implementation of the policy matrix as shown in Table 1.

The matrix describes the stages and details of the work that must be carried out by the policy implementer so that each stage clearly illustrates the work that must be carried out by the policy implementer, so that the policy implementation can be carried out properly. By referring to the matrix, a flow of policy implementation guided through the diagram model can be made. 
Table 1. Stages of Management Policy Implementation Activities

\begin{tabular}{|c|c|c|}
\hline No & Stages & Important Issue \\
\hline & Strategic phase (pre implementation) & $\begin{array}{ll}\text { 1. } & \text { Adjust organizational structure with strategy } \\
\text { 2. } & \text { Institutionalize strategy } \\
\text { 3. } & \text { Operationalize the strategy } \\
\text { 4. } & \text { Use procedures to facilitate implementation } \\
\text { 5. } & \text { Organizational design and organizational structure }\end{array}$ \\
\hline & Organizing & $\begin{array}{ll}\text { 1. } & \text { Division of work and job design } \\
\text { 2. } & \text { Integration and coordination } \\
\text { 3. } & \text { Recruitment and staffing } \\
\text { 4. } & \text { Rights, authority and obligations } \\
\text { 5. } & \text { Delegation (centralization and decentralization) } \\
\text { 6. } & \text { Development of organizational capacity and human resource capacity } \\
\text { 7. } & \text { Organizational culture }\end{array}$ \\
\hline & Mobilization and Leadership & $\begin{array}{ll}\text { 1. } & \text { Leadership effectiveness } \\
\text { 2. } & \text { Motivation } \\
\text { 3. } & \text { Ethics } \\
\text { 4. } & \text { Quality } \\
\text { 5. } & \text { Teamwork } \\
\text { 6. } & \text { Organizational communication } \\
\text { 7. } & \text { Negotiation }\end{array}$ \\
\hline & Control & $\begin{array}{ll}\text { 1. } & \text { Control design } \\
\text { 2. } & \text { Management information System } \\
\text { 3. } & \text { Budget/financial control } \\
\text { 4. } & \text { Audit }\end{array}$ \\
\hline
\end{tabular}

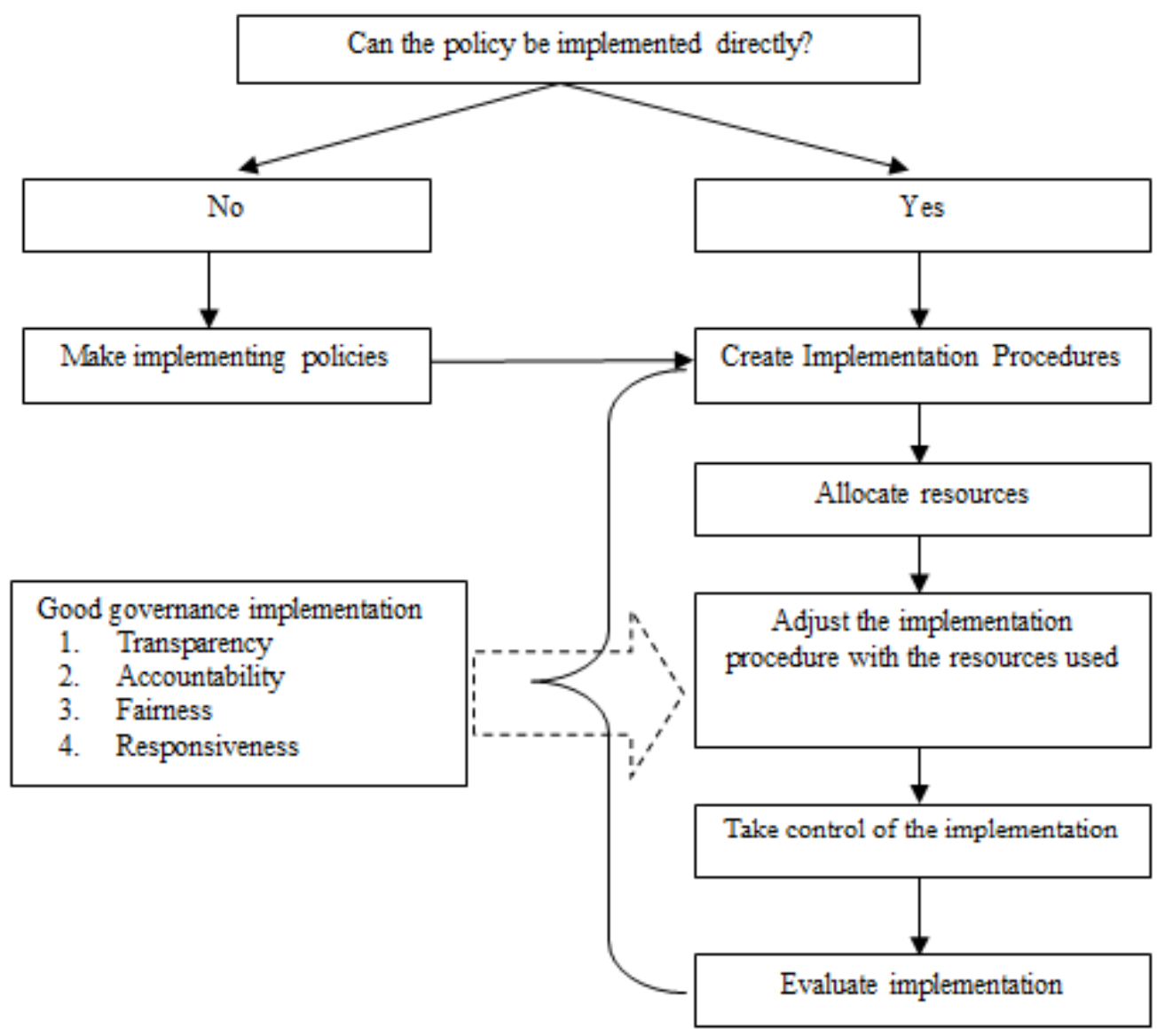

Figure 2. Standard Operational Procedure 
The model above illustrates that the main problem in implementing policies is how the policies are made and then adjusted to the available resources. In addition, in adjusting implementation procedures with the resources used there is a necessity for the implementation of good governance. Namely the implementation of policies must have transparency, accountability, fairness, and responsiveness.

In the last two decades, the large push from the public to implement the principles of the rule of law and accountability in government and public services has given birth to a new paradigm of good governance. The tasks and functions of the government are reformulated to avoid centralizing power. The Ministry of Administrative Reform (2005) states that there are 10 principles that must be implemented to achieve the goals of good governance, namely:

1. Participation, guaranteeing the cooperation and participation of stakeholders, starting from the planning, implementation and evaluation stages.

2. Law enforcement, carried out consistently, paying attention to human rights, including providing incentives.

3. Transparency, information that is open to each party for each stage of government.

4. Responsiveness, appropriate and fast response to problems or changes that occur.

5. Equality, equality for citizens without discrimination.

6. Strategic vision, the availability of integrated and long-term policies and plans.

7. Efficiency in resource use.

8. Professionalism, skills and commitment to provide the best service.

9. Accountability, being responsible to the public for the decisions and actions of the organizer.

10. Supervision, the availability of effective supervision with community involvement.

According to Ida (2002), the requirements for creating good governance, namely: creating efficiency, public accountability, the availability of adequate legal infrastructure and the existence of information systems can guarantee public access and transparency. Education policy is one aspect of state administration that must be carried out within the framework of good governance in order to achieve the goal of quality education.

In the implementation of Dwijowijoto's (2004) theoretical framework, it was emphasized that good governance needs to be carried out by some means of transparency, accountability, fairness, and responsiveness. Transparency, namely the implementation of policies at each stage, must be open and widely accessible to the public. Accountability, i.e., it can be accounted so that supervision must be carried out by both the determinant, implementer and policy user. Fairness is that the user or community must truly obtain opportunities and rights proportionally, and responsiveness means that the implementation of the policy is really taken into account and meets the needs of the user community.

\section{Main Components of Education Policy Implementation}

\subsection{Translation Ability}

The ability of implementers to translate or understand a policy (translation ability) to be implemented will greatly affect the success of a regional autonomy policy in education. The main component of translation ability is human resources as a determinant and implementer of education policy towards the regional autonomy policy in education.

Human resources as determinants and implementers of the regional autonomy policy in the field of education are influenced by its quality. Skelcher (1992) states that service quality is very closely related to equality. Further it was stated that with the development of service quality involving thinking about customers as individuals, it is also important to recognize that they are members of certain groups, which are defined in terms of gender, ethnic origin, age, physical abilities or other characteristics.

Understanding of the determinants and implementers of the regional autonomy policy in the education sector towards educational policy in the form of legislation will largely determine an educational policy that can be implemented in accordance with the objectives. According to Sigler and Beede (1977), facilities are needed to realize the goals that have been selected and determined so that they can be realized in the community. One of the adequate means is the law with various forms of existing laws and regulations.

\subsection{Equality and Equity}

Quality not only emphasizes the importance of satisfaction for individuals, but also all members of society without looking at differences in sex, race, ethnicity, and other differences. In Priorities and Strategies for Education, the World Bank (1995) states that equality - equity in education services often results in disadvantages for the poor and ethnic minority groups, and the children of street workers. In the context of implementing regional autonomy policy in the field of education which is a public service, humans must be able to provide the same service for each individual as a member of the community (equality).

To measure the implementation of public policies including educational policies, there are many concepts developed by experts, but according to Skelcher (1992) there are three concepts that are important for formulating and measuring service quality, namely economy, efficiency, and effectiveness. After conducting a study on 
the decentralization of education in Indonesia, Sirat (2010) recommends measuring the implementation of the regional autonomy policy in the education sector, namely economy, efficiency, effectiveness, transparency, and accountability (see also, Therkildsen, 2001).

\subsection{Accountability}

Efforts to increase human resources both in quantity and quality can be seen by using indicators of economy, efficiency, effectiveness, transparency, and accountability. Thus, every activity to increase human resources can be done by considering the funds or budget adjusted to the needs (economy) that must be done by utilizing or empowering human resources, funds and available facilities (efficiency). This is done to meet the needs in improving organizational performance and to support the achievement of programmed goals (effectiveness), and must be carried out objectively and transparently according to the provisions in force ( transparency), and must be truly accountable (accountability).

Education development is a process of ongoing changes. To make changes requires law as a means to make changes in society. The law is recognized as very important as a means to realize government policies because the law is a series of tools to realize government policies. According to Seidman (1978), policymakers have only one tool that can be used to influence the activities of stakeholders. The tool is the rules made. The law provides legitimacy for the implementation of government policies. As a statutory regulation, this has proven the law as a tool for implementing policies.

\subsection{Supporting Legislation}

In order to organize education and direct the community to fit the desired objectives, the use of law as a means of implementing policies has an important meaning as confirmed by Dror (1968) that the consideration of all relevant legal systems is an important condition for effective and efficient use of law as an instrument of targeted social change. Here, the legal system becomes a sub-system of society, so the consideration of legal policy instruments is realized in the abstraction of other social policy instruments. Given the very strategic nature of the law in the form of legislation as a policy, it is necessary to understand by the policy makers and implementers of the laws and regulations as a policy. Policy makers must understand a variety of higher policies so that implementing policies that are determined do not conflict with higher policies and policies that will be determined are truly able to provide direction for the implementation of education policies. As the implementer of regional autonomy policy in the field of education, understanding policy determinants of laws and regulations as an absolute policy must be had. If the implementer of the policy does not understand a policy, the policy objectives will not be achieved.

\section{Factors Influencing Public Policy Implementation}

A public policy according to Dwidjowijoto (2004) can be influenced by several factors, namely: (1) implementation activities and communication between organizations, (2) characteristics of implementing agencies (3) economic, social, and political conditions, and (4) the tendency (deposition) of the executor. Furthermore Nugraha stated that besides these four factors there were also factors outside public policy that influenced implementation, namely: (a) indicators of socio-economic-technological conditions, (b) public support, (c) attitudes and resources from constituents, (d) higher official support, (e) commitment and leadership quality from implementing officials.

The actual policy implementation concerns not only the behavior of the administrative bodies responsible for implementing the program and causing adherence to the target group, but also the network of forces that can influence the behavior of all parties involved and which ultimately influences the expected good impact or unexpected. Implementation of public policy is closely related to human factors with various backgrounds in society, culture, and so on (Sunggono, 1994). One of the factors that determine the success or failure of a policy is the capacity to carry out the policy as planned. As stated by Grindle (1980) that a general process of success and failure can be evaluated in terms of the capacity to deliver programs as designed.

Dwiyanto (2002) focuses more on internal factors stating there are several factors that influence the implementation of public policies, including: (1) bureaucratic culture, (2) service ethics, (3) discretionary authority, and (4) incentive system. From the description above it can be concluded that the successful implementation of a public policy is very dependent on (1) organizational resources (human, financial, facilities), (2) the ability of implementing management, and (3) the support of the policy environment, both in terms of political, social, economy and security.

Non-compliance and non-implementation of public policy by community members, according to Anderson (1979) were caused by several factors:

1) The concept of selective non-compliance with the law because there are several laws or public policies that are not bound on individuals;

2) Membership of a person in a group or association that has ideas or thoughts that are not in accordance with or contrary to the rule of law or the wishes of the government; 
3) There is a desire to seek profits quickly among community members who tend people to act by deception or by way of breaking the law;

4) There are legal uncertainties or unclear "measures" of policies which (may) conflict with one another which can be a source of non-compliance with the law or public policy;

5) The existence of a policy is sharply opposed (contrary) to the value system adopted by the wider community or certain groups in society.

Weissert and Goggin (2004) state that political support and commitment from stakeholders (politicians, bureaucracy, direct policy targets, and the wider community) to implement policies that have been decided are the basic capital for the success of a policy. Meanwhile, financial adequacy, an effective and efficient managerial system, and the technical capabilities of the executor are the main requirements for the implementation of a public policy. Furthermore Weimer and Vining (1992) state that the success of a public policy is strongly influenced by 3 factors. These factors as the focus of many things are the logic of the policy, the nature of the cooperation it needs, and the availability of skilled and committed people to manage its implementation (Weimer and Vining 1992).

The logical and rational policy content factor, cooperation and stakeholder support, and skilled and committed human resources in implementing policies are factors that determine the success of a public policy. However, Weimer and Vining (1992) pay less attention to the problem of financial resource support which is actually no less important than the three factors above in implementing a policy.

More clearly, Gerston (1992) states that the success of a public policy implementation can be influenced by 4 factors, namely: (1) translation ability, namely the ability of implementing staff to translate what has been decided by decision makers to be implemented, ( 2) resources, especially those related to human resources, finance, and equipment/facilities, (3) the limited number of players, namely the number of policy implementers that are not too many, so as not to cause confusion and unfair competition, and (4) accountability, namely the existence of a accountable process of implementing the policy for what has been produced.

Compared with other theories, the theory of Gerston's public policy implementation when used to analyze the implementation of public policy in the education sector in the framework of regional autonomy in Indonesia is the most appropriate theory although it needs to be adopted with various adjustments to better suit the reality of the implementation of education policy in Indonesia today. Grindle (1980) reminded policy makers and field implementers of the possibility of a gap between the policy objectives taken and the results achieved in the field.

From various theories of public policy implementation presented, Baedhowi (2009) states that Gerston's (1992) theory which requires the existence of four factors that influence the implementation of public policy is a relevant theory and is more suitable for analyzing the implementation of public policy in education in the framework of regional autonomy in Indonesia, although it does not have to be adopted exactly. Therefore, some adjustments or modifications need to be done.

Baedhowi (2009) further explains that adjustments need to be made especially on the second factor, namely resources. Resources are broken down into several components and human resource staff (personnel) are included in the HR component which is part of the translation ability component. This adjustment is made on the basis of human resources very closely related to understanding or translation ability. The task - the bureaucracy is made a separate component covering the organizational and management components because this component is one of the important components in an organization that needs to be emphasized. Infrastructure (equipment) was also appointed as a separate component because facilities and infrastructure were the bridging factor between bureaucracy and policy implementation.

Likewise, funds/costs (funding) are separated into separate components. In addition, the third component of Gerston's (1992) theory of limited numbers of players, who in principle are the parties supporting the policy implementation process, is integrated with the human resource (HR) sub-component which is part of the translation ability component. The fourth component of Gerston accountability is implicitly included in the four components because essentially accountability must be carried out throughout the entire component of policy implementation. The modification of Gerston's (1992) theory is very compatible with the reality of how education policies are implemented in Indonesia. With four factors, namely translation ability, organization and management, education funding, and facilities and infrastructure, it will be known how the implementation of education policy is carried out. 
Gerston's Framework

Adaptation

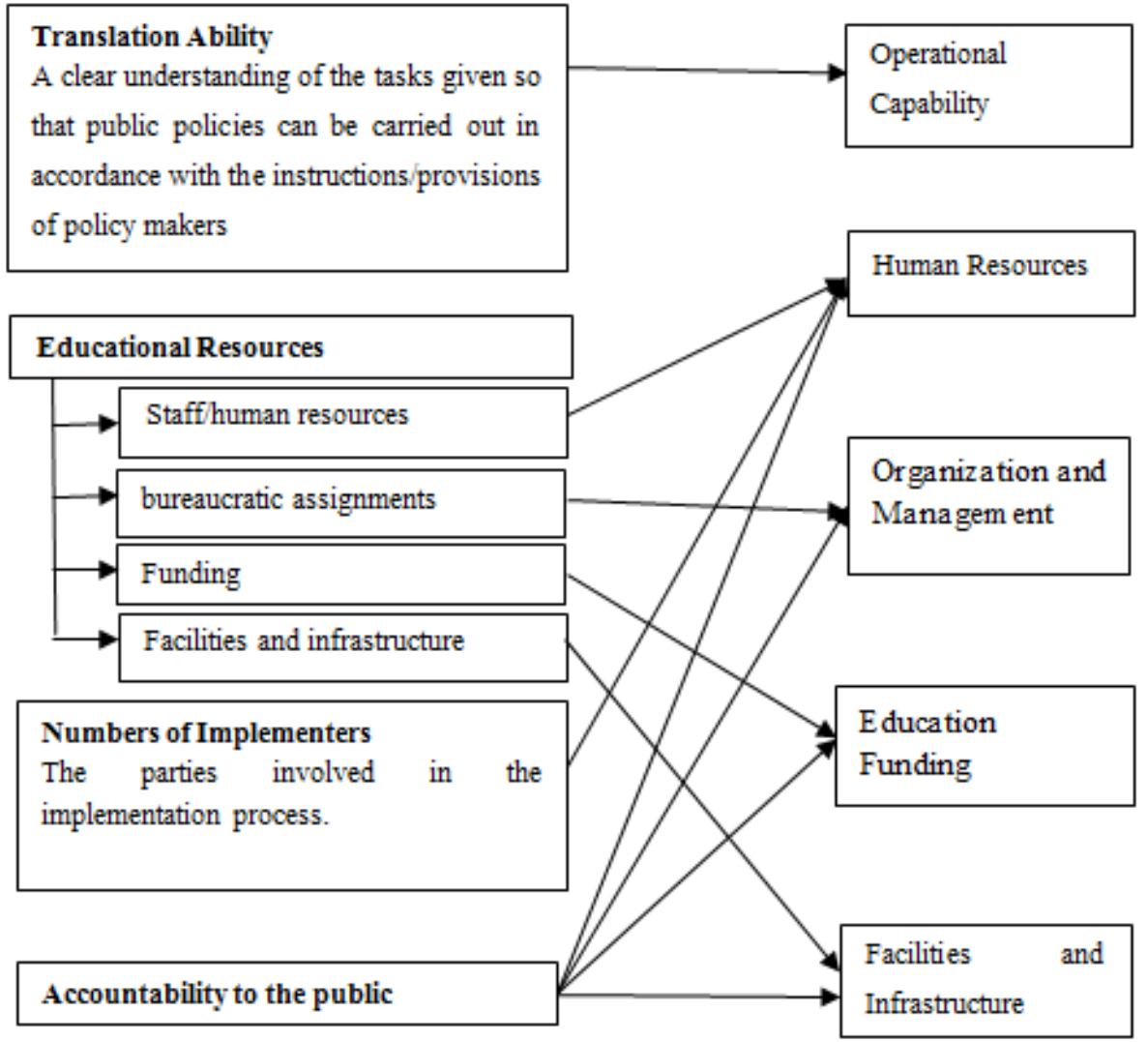

Figure 3. Framework for Educational Policy Implementation

\section{Conclusions}

Every policy is directed to achieve a certain goal as outlined and policy implementation is a process to carry out or realize the goals outlined into reality. Thus the implementation of education policy has a very important position of the education policy itself, because a policy will only be planned if it is not implemented. The failure occurred in the implementation because the implementation process will always be related to the environment. Every policy in the form of laws and regulations in its implementation cannot be separated from its environment, which is called interaction with human, socio-cultural elements and so on.

Educational policy as a system, on the one hand takes materials as input, to be further processed to subsequently produce permanence as output. In connection with this, in reality every educational regulation and policy will always change, both through formal changes and changes made by the bureaucracy when acting. The implementation of public policy is essentially aimed at forming a relationship that enables policy objectives to be realized. In the analysis of public policy implementation, bureaucracy is one of the variables that influence the implementation process, in addition to other factors that also influence it.

This study makes an important model framework in the implementation of education policy in Indonesia. Based on Gerston's theory, the results of the study revealed that important considerations in the implementation of education were related to translation ability, capability of personnel/human resource management, the number of implementers and accountability. With the modification of the theory, it is deemed compatible with the reality of how education policies are implemented in Indonesia.

The findings of this study underline the important role of mid-level managers' abilities, especially with regard to translation ability. This ability is related to the ability to translate regulations and policies at a higher level so that they can be implemented at the lower level. In addition, the results of observations of the implementation of education policies in local government in Indonesia also found that secondary level education managers had a substantial role. Various things that need to be done by the government as regulators and executives in practice are to ensure that there are sufficient secondary level education managers to handle various educational problems. This is because, unfortunately, most implementations nowadays only focus on the school level and do not see that on many occasions, schools have difficulty meeting the standards applied because of the lack of assistance from secondary level education managers and education supervisors at higher levels. In addition, in accordance with the perspective of 
management accounting in education, this study also encourages the principle of educational accountability to be improved by using more relevant agency roles to encourage accountable reform in schools or using more assessments to assess school success and fulfillment and compliance educational institutions on policy standards and references.

\section{REFERENCES}

[1] Adomssent, M., Fischer, D., Godemann, J., Herzig, C., Otte, I., Rieckmann, M., \& Timm, J. (2014). Emerging areas in research on higher education for sustainable developmentmanagement education, sustainable consumption and perspectives from Central and Eastern Europe. Journal of Cleaner Production, 62, 1-7.

[2] Anderson, J.E. (1979). Public Policy Making. New York: Holt, Rinehart and Winston.

[3] Atasoy, R., \& Cemaloglu, N. (2018). Evaluation of Quality Policies on Education in Turkish Education System. Universal Journal of Educational Research, 6(7), 1504-1518.

[4] Baedhowi. (2009). Kebijakan Otonomi Daerah Bidang Pendidikan. Semarang: Pelita Insani.

[5] Bjork, C. (2003). Local responses to decentralization policy in Indonesia. Comparative Education Review, 47(2), 184-216.

[6] Bjork, C. (2005). Indonesian education: Teachers, schools, and central bureaucracy. Routledge.

[7] Coburn, C. E., Hill, H. C., \& Spillane, J. P. (2016). Alignment and accountability in policy design and implementation: The Common Core State Standards and implementation research. Educational Researcher, 45(4), 243-251.

[8] Daft, R. L., \& Lane, P. G. (2007). Understanding the theory and design of organizations. Mason, $\mathrm{OH}$ : Thomson South-Western.

[9] Davies, L., Harber, C., \& Dzimadzi, C. (2003). Educational decentralisation in Malawi: a study of process. Compare: A Journal of Comparative and International Education, 33(2), 139-154.

[10] DeFeo, D. J., Berman, M., \& Hirshberg, D. (2018). Statute and Implementation: How Phantom Policies Affect Tenure Value and Support. Educational Policy, 0895904818773917.

[11] del Mar Alonso-Almeida, M., Marimon, F., Casani, F., \& Rodriguez-Pomeda, J. (2015). Diffusion of sustainability reporting in universities: current situation and future perspectives. Journal of cleaner production, 106, 144-154.

[12] Dror, Y. (1968). Public Policymaking Re-examined. Scranton: Chandler Publishing Co.

[13] Dwijowijoto, N.R. (2004). Kebijakan Publik Formulasi, Implementasi, dan Evaluasi. Jakarta: Elex Media
Komputindo.

[14] Dwiyanto, A. (2002). Reformasi Birokrasi Publik. Yogyakarta: Center for Population and Policy Studies, Universitas Gajah Mada.

[15] Edwards Jr, D. B., \& DeMatthews, D. (2014). Historical trends in educational decentralization in the United States and developing countries: A periodization and comparison in the post-WWII context. Education policy analysis archives, 22, 40.

[16] Egilmez, N. I. (2018). Comparison of Mother Tongue Teaching Curriculums Implemented at the Middle School Level in Turkey and England. Universal Journal of Educational Research, 6(10), 2384-2398.

[17] Elmore, R. F. (2002). Unwarranted intrusion: isn't it ironic that Republicans sponsored the single largest--and potentially the single most damaging--expansion of federal power over the nation's education system in history? Education Next, 2(1), 31-36.

[18] Elmore, R. F. (2004). School reform from the inside out: Policy, practice, and performance. Harvard Education Press. 8 Story Street First Floor, Cambridge, MA 02138.

[19] Freeman, R. E. (2005). The development of stakeholder theory: An idiosyncratic approach. Great minds in management: The process of theory development, 417-435.

[20] Fullan, M. (1994). Coordinating top-down and bottom-up strategies for educational reform. Systemic reform: Perspectives on personalizing education, 7-24.

[21] Gamage, D., \& Sooksomchitra, P. (2006). Decentralisation and school-based management in Thailand. In Decentralisation and Privatisation in Education (pp. 151-167). Springer, Dordrecht.

[22] Gershberg, A. I., Meade, B., \& Andersson, S. (2009). Providing better education services to the poor: Accountability and context in the case of Guatemalan decentralization. International Journal of Educational Development, 29(3), 187-200.

[23] Gerston, N. (1992). Public Policymaking in a Democratic Society. A Guide to Civic Engagement. New York: M.E. Sharp, Inc.

[24] Ghozali, A,. (2012). Sistem Pendanaan Pendidikan di Indonesia. Seminar Nasioanal Redesain Sistem dan Desentralisasi Pendidikan. Yogyakarta: ISPI.

[25] Gilbert Jr, D. R. (1996). The prisoner's dilemma and the prisoners of the prisoner's dilemma. Business Ethics Quarterly, 165-178.

[26] Gillespie, C. W., \& Fairbairn, S. (2019). Changing Educational Policies in the United States and India: Perspectives of Teacher Educators. The Teacher Educator, $1-19$.

[27] Grindle, M. S. (1980). Politics and Policy Implementation in the Third World, New Jersey: Princetown University Press

[28] Honig, M. I. (2004). The new middle management: Intermediary organizations in education policy implementation. Educational Evaluation and Policy Analysis, 26(1), 65-87. 
[29] Honig, M. I. (2006). Street-level bureaucracy revisited: Frontline district central-office administrators as boundary spanners in education policy implementation. Educational Evaluation and Policy Analysis, 28(4), 357-383.

[30] Ida, L. (2002). Otonomi Daerah, Demokrasi Lokal, dan Clean Goverenment. Jakarta: PSPK

[31] Klugman, J. (1994). Decentralisation: A survey of literature from a human development perspective. UNDP Human Development Report Office.

[32] Kristiansen, S. (2006). Decentralising education in Indonesia. International journal of educational development, 26(5), 513-531.

[33] Liu, S., Liu, F., \& Yu, Y. (2017). Educational equality in China: Analysing educational policies for migrant children in Beijing. Educational Studies, 43(2), 210-230.

[34] Mbiti, I. M. (2016). The need for accountability in education in developing countries. Journal of Economic Perspectives, 30(3), 109-32.

[35] Ministry of Administrative Reform of the Republic of Indonesia. (2005). Clean Goverenmen dan Good Goverenment Untuk Meningkatkan Kinerja Birokrasi dan Pelayanan Publik. Jakarta: Ministry of Administrative Reform of the Republic of Indonesia.

[36] Muhdi, M. (2012). Pengembangan model Implementasi kebijakan pendidikan Kota Semarang pada era otonomi daerah. (Dissertation, Semarang State University)

[37] Ornelas, C. (2000). The politics of the educational decentralization in Mexico. Journal of Educational Administration, 38(5), 426-442.

[38] Ornelas, C. (2004). The politics of privatisation, decentralisation and education reform in Mexico. International Review of Education, 50(3-4), 397-418.

[39] Rollan, K., \& Somerton, M. (2019). Inclusive education reform in Kazakhstan: civil society activism from the bottom-up. International Journal of Inclusive Education, $1-16$.

[40] Samosir, M. (2008). The Effects of Decentralization on Education in Indonesia: Education for All?. Master Theses in Public Policy and Human Development. Universiteit Maastrich. Maastrich Graduate School of Governance. The Netherlands.

[41] Schiefelbein, E. (2004). The politics of decentralisation in Latin America. International Review of Education, 50(3-4), 359-378.

[42] Seidman, R. B. (1978). The State, Law, and Development (p. 34). London: Croom Helm.

[43] Seow, P., Looi, C. K., How, M. L., Wadhwa, B., \& Wu, L. K. (2019). Educational Policy and Implementation of Computational Thinking and Programming: Case Study of Singapore. In Computational Thinking Education (pp. 345-361). Springer, Singapore.

[44] Sidi, I.J. (20010. Menuju Masyarakat Belajar, Menggagas Paradigma Baru Pendidikan, Jakarta: Paramadina dan PT Logos Wacana Ilmu.

[45] Sigler, J. A., \& Beede, B. R. (1977). The legal sources of public policy. Lexington Books.

[46] Simatupang, R. R. (2009). Evaluation of decentralization outcomes in Indonesia: Analysis of health and education sectors.

[47] Sirat, M. B. (2010). Strategic planning directions of Malaysia's higher education: University autonomy in the midst of political uncertainties. Higher education, 59(4), 461-473.

[48] Skelcher, C. (1992). Managing for Service Quality. Essex: Longman Group.

[49] Spillane, J. P. (2000). Cognition and policy implementation: District policymakers and the reform of mathematics education. Cognition and instruction, 18(2), 141-179.

[50] St. Amant, K. (2003). Expanding internships to enhance academic-industry relations: A perspective in stakeholder education. Journal of Technical Writing and Communication, 33(3), 231-241.

[51] Stinnette, L. J. (1993). Decentralization: Why, How, and toward What Ends? Special Policy Report, No. 1. Policy Briefs Series.

[52] Sunggono, B. (1994). Hukum dan Kebijaksanaan Publik. Jakarta: Sinar Grafika.

[53] Therkildsen, O. (2001). Efficiency, accountability and implementation: public sector reform in East and Southern Africa (pp. 1-39). Geneva: United Nations Research Institute for Social Development.

[54] Toi, A. (2010). An empirical study of the effects of decentralization in Indonesian junior secondary education. Educational Research for Policy and Practice, 9(2), 107-125.

[55] Wael, B., \& Laurens, S. (2015). Policy Implementation of Special Autonomy Funds: Case Study Of Education Funding In The District Manokwari West Papua, Indonesia. International Journal of Scientific \& Technology Research Vol., 4.

[56] Wankel, C., \& Stoner, J. A. (Eds.). (2009). Management education for global sustainability. IAP.

[57] Weimer, D. L., \& Vining, A. R. (1999). Policy Analysis: Concepts and Practice. New Jersey: Prentice Hall.

[58] Weissert, C. S., \& Goggin, M. L. (2002). Non-incremental policy change: Lessons from Michigan's Medicaid managed care initiative. Public Administration Review, 62(2), 206-216.

[59] Winkler, D. R. (1989). Decentralization in education: An economic perspective (Vol. 143). World Bank Publications.

[60] Wyse, D., \& Ferrari, A. (2015). Creativity and education: Comparing the national curricula of the states of the European Union and the United Kingdom. British Educational Research Journal, 41(1), 30-47.

[61] Xu, X., \& Mei, W. (2018). Educational policies and legislation in China. Springer Singapore.

[62] Yarime, M., Trencher, G., Mino, T., Scholz, R. W., Olsson, L., Ness, B.,... \& Rotmans, J. (2012). Establishing sustainability science in higher education institutions: 
towards an integration of academic development, institutionalization, and stakeholder collaborations. Sustainability Science, 7(1), 101-113.

[63] Young, T., \& Lewis, W. D. (2015). Educational policy implementation revisited. Educational Policy 29 (1): 3-17. 